\title{
Penerapan teknik digital prototyping dalam perancangan dan pembuatan model produk berbasis generative design
}

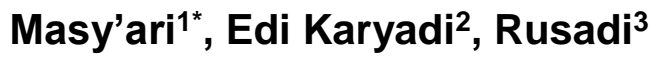 \\ 1,2,3 Jurusan Teknik Mesin, Politeknik Negeri Pontianak \\ Jl. Akhmad Yani, Pontianak, Indonesia \\ *Corresponding author:masyari_ari@yahoo.com
}

\begin{abstract}
Digital prototyping is an innovative design method. With digital product prototyping techniques that are designed with the concept of Generative Design and Topology Optimization, the designer able to visualize and simulate the product start from the design, stress analysis to the product manufacturing process. The aim of this research is to optimization the topology of the product model results of generative design, determine the strength of the model through Stress Analysis used topology optimization 50\%, 60\%, and 70\% of the product model results of generative design and figure the results of the product $3 D$ printing in made prototype models as a result of generative design. This research is conducted in 3 steps, that is the preparation of made models with computing Autodesk Inventor Professional 2020, the analysis with generative design, and the printed with $3 D$ printing. This $3 D$ printed product is made in 2 models. Model 1 with a material reduction of $70 \%$ topology optimization was better than $50 \%$ or $60 \%$ material lighting. Model 2, the maximum of $50 \%$ Von Mises Stress reduction is smaller than the $60 \%$ and $70 \%$ reduction.
\end{abstract}

Keywords: Digital prototyping, generative design, topology optimization

\begin{abstract}
Abstrak
Digital prototyping adalah metode desain yang inovatif. Dengan teknik digital prototyping produk yang didesain dengan konsep generative design dan topology optimization perancang dapat memvisualisasikan dan mensimulasikan produk yang akan dibuat mulai dari rancangannya, analisis kekuatan sampai proses pembuatan produk. Tujuan dari penitian ini adalah untuk melakukan optimasi topologi dari model produk hasil generative design, mengetahui kekuatan model melalui stress analysis menggunakan optimasi topologi $50 \%, 60$ $\%$, dan $70 \%$ dari model produk hasil generative design dan mengetahui hasil produk yang dibentuk dengan 3D printing dalam pembuatan prototype model hasil generative design. Penelitian ini dilakukan dalam 3 tahap, yaitu tahap persiapan pembuatan model dengan komputasi Autodesk Inventor Professional 2020, tahap analisa dengan generative design dan tahap pencetakan dengan 3D printing. Produk yag dicetak dengan 3D ini dibuat dalam 2 model. Hasil penelitian menunjukkan bahwa model 1 dengan pengurangan material sebesar $70 \%$ bentuk optimasi topologi lebih baik dibandingkan dengan pengurangan material $50 \%$ maupun $60 \%$. Untuk model 2 pengurangan material $50 \%$ Von Mises Stress maksimumnya lebih kecil dibandingkan dengan pengurangan $60 \%$ dan $70 \%$.
\end{abstract}

Kata kunci: Digital prototyping, generative design, topology optimization.

\section{Pendahuluan}

Perkembangan Ilmu Pengetahuan dan Teknologi (IPTEK) di negara maju sangat pesat sekali. Kita sering membicarakan Revolusi Industri 4.0, pemanfaatan Teknologi Informasi dan Komunikasi (TIK) dalam dunia industri (digital transformation of manufacturing) dimana para desainer dituntut tidak hanya menghasilkan desain yang berfungsi dengan baik, aman, dan kuat namun secara estetika 
produk yang dihasilkan dapat diterima oleh pasar dan memiliki inovasi. Indonesia sebagai negara berkembang menerima dampak kemajuan teknologi tersebut, antara lain, kita menyaksikan pekerjaan yang dioperasikan manusia telah digantikan oleh mesin berbasis TIK. Dengan kemajuan teknologi, pembuatan suatu produk menjadi semakin mudah dan lebih murah serta dapat menggunakan metode yang bervariasi seperti menggunakan printer 3 dimensi dan menggunakan CNC (Computer Numerical Controlled) yang sebelumnya perancangan dilakukan menggunakan program aplikasi di komputer [1]. Produk dengan bentuk yang komplek sangat sulit dibuat dengan cara yang konvensional atau dengan cara manual, oleh karena itu digunakanlah teknik digital prototyping. Dengan teknik digital prototyping sangat membantu terlebih lagi komponen yang dibuat dapat langsung dilihat bentuknya dan dapat langsung dipasang (assembly).

Digital prototyping adalah metode desain yang inovatif. Digital prototyping memberikan desain konseptual, teknik dan manufaktur yang secara virtual dapat mengeksplorasi benda secara detil sebelum dibuat. Dengan menggunakan teknik digital prototyping perancang dapat merancang, memvisualisasikan dan mensimulasikan produk yang akan dibuat mulai dari rancangannya, analisis kekuatan sampai proses pembuatan produk. Teknik ini mampu mengurangi kesalahan dalam perancangan dan dapat mengurangi biaya kerugian akibat kegagalan pembuatan produk.

Adapun tujuan dari penelitian ini adalah untuk merancang dan membuat model produk menggunakan teknik digital prototyping dengan melakukan optimasi topologi dari model produk hasil generative design menggunakan mesin printer 3 dimensi. Berdasarkan hasil laporan khusus situs engineering.com untuk saat ini ada dua tren yang paling banyak dibicarakan di komunitas desain produk yakni generative design dan topology optimization, seperti yang terlihat pada Gambar 1. Teknik simulasi ini memungkinkan customers untuk merancang bagian yang ringan dan performatif menggunakan pendekatan desain yang digerakkan oleh simulasi. Kemajuan teknologi manufaktur juga memungkinkan desain rumit ini dapat dibuat menggunakan proses tradisional seperti casting, injection molding, dan forging, tetapi juga melalui Additive Manufacturing (AM) atau pencetakan 3D [2].

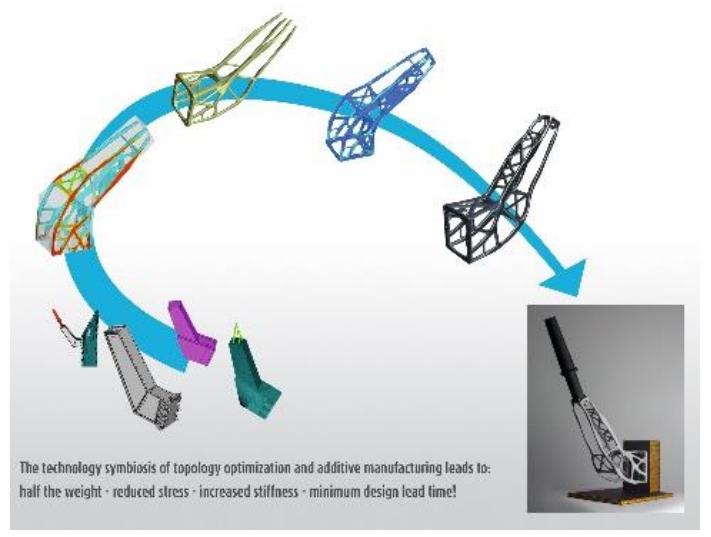

Gambar 1. Konsep Generative Design dan Topology Optimization [2]

Metode 3D printing memiliki banyak penyetelan pada printernya untuk membuat komponen dengan hasil yang baik dari segi bentuk dan ukurannya. Untuk mendapatkan hasil yang baik tersebut harus dilakukan pengujian terlebih dahulu terhadap beberapa kondisi cetak mesin printer 3 dimensi [3]. Kondisi cetak yang dapat dijadikan parameter yaitu kerapatan struktur di dalam benda yang dicetak (infill), suhu pencetakan yaitu suhu pada nosel (print temperature), ketinggian antarlapisan (layer heigh), dan kecepatan mencetak (print speed). Masing-masing parameter ini dapat diatur di dalam aplikasi Ultimaker Cura sebelum pencetakan dimulai. Pengaturan parameter tersebut dapat divariasikan sesuai target yang diinginkan dengan konsekuensi seperti waktu pencetakan dan bentuk hasil cetakan.

Dengan teknik digital prototyping produk yang didesian dengan konsep generative design dan topology optimization ini diharapkan mampu mengurangi waktu dan biaya pembuatan. Komponen yang dibuat dapat langsung jadi dan untuk 
komponen yang memiliki bentuk sangat komplek, hasilnya menjadi lebih teliti jika dibandingkan dengan cara manual. Perancangan dan pembuatan suatu produk menggunakan teknik digital prototyping juga tidak memerlukan peralatan yang banyak dan proses pembuatannya dilakukan oleh sistem komputerisasi sehingga risiko terjadi kesalahan ataupun human eror sangat minim.

\section{Tinjaun Pustaka}

\section{Printer 3 Dimensi}

Secara umum, prinsip kerja mesin cetak tiga dimensi tidak jauh berbeda dengan printer pada umumnya. Ilustrasi proses cetak menggunakan 3D printer ditunjukkan pada Gambar 2.

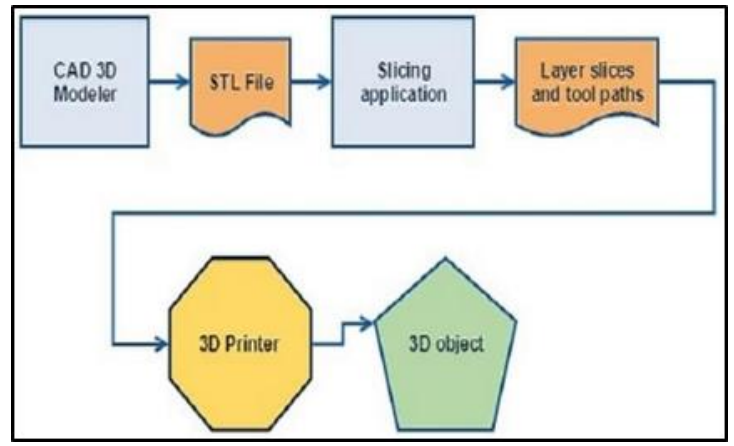

Gambar 2. Diagram alir proses 3D Printing [4].

Desain objek yang akan dibuat terlebih dahulu harus dikonversi ke dalam beberapa format file yang relevan dengan aplikasi yang digunakan. Desain awal objek menggunakan aplikasi CAD dengan format gambar.$d w g$ atau langsung dikerjakan dalam aplikasi inventor maupun solidwork atau aplikasi pemodelan lain yang relevan. Hasil desain kemudian disimpan dalam format stl untuk membentuk lapisan-lapisan yang membentuk objek menggunakan aplikasi pencetakan tiga dimensi Cura [4].

\section{Generative Design dan Topology Optimization \\ Metode generative design} merupakan sebuah metode dimana desainer menggunakan komputer untuk membantu menghasilkan sejumlah solusi berdasarkan suatu kriteria, batasan, dan goal yang dikehendaki yang kemudian di masukkan dalam program, kemudian komputer melalui algoritmanya melakukan iterasi dan hasil solusi yang diperoleh menjadi dasar ide untuk diputuskan dan diterapkan. Melalui ide yang berasal dari desainer oleh sejumah algoritma digunakan untuk memerintahkan komputer cara dan bagaimana proses penyelesaian masalah tersebut dilakukan oleh algoritma tersebut di terjemahkan menjadi bahasa program lalu komputer akan melakukan komputasinya sehingga menghasilkan luaran yang terdiri dari berbagai macam varian solusi yang baru. Dari varian solusi tadi, desainer mengambil keputusan dalam pemilihan varian yang dikehendaki, biasanya faktor estetika menjadi pertimbangan dalam memutuskan [5].

Optimasi topologi ini dilakukan dengan menggunakan perangkat lunak Autodesk Inventor 202, dimana fitur Shape Generator digunakan dalam perangkat lunak tersebut untuk melakukan optimasi dari model awal namun dengan reduksi massa dan tetap mempertahankan integritas dari struktur, selain itu hasil dari bentuk model geometri yang diperoleh diuji kembali dengan metode FEA agar memastikan hasil dari bentuk geometri tersebut memenuhi kriteria desain dan aman.

\section{Metode Penelitian}

Penelitian dilaksanakan di Laboratorium Jurusan Teknik Mesin Politeknik Negeri Pontianak.

Alat dan bahan yang digunakan adalah:

1) Unit komputer/laptop

2) Printer 3 dimensi

3) Uninterruptible power supply (UPS)

4) Filament PLA

Data yang dikumpulkan yang berkaitan dengan ukuran dan bentuk model produk yang akan didesain menggunakan konsep Generative Design Autodesk Inventor Professional 2020.

Technical Data Sheet PLA, seperti yang terlihat pada Tabel 1 . 
Tabel 1. Technical Data Sheet PLA

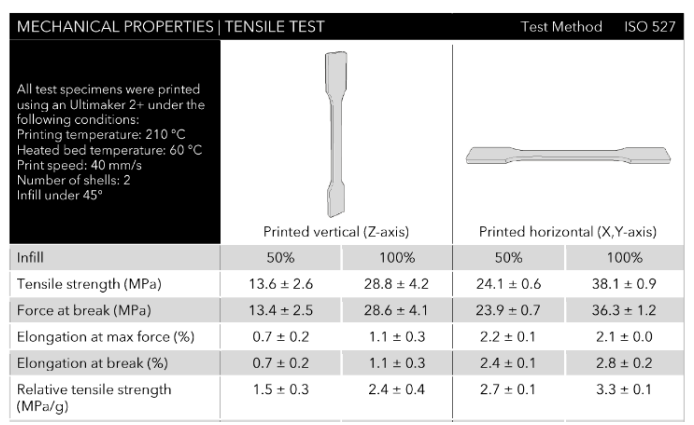

\section{Pembuatan model}

Dalam penelitian ini dibuat 2 bentuk model, yaitu model tangan piston (model 1) dan engine mounting (model 2). Pemilihan 2 bentuk model tersebut didasarkan pada model dapat dilakukan uji tarik. Gambar pemodelan dapat dilihat pada Gambar 3 dan 4.

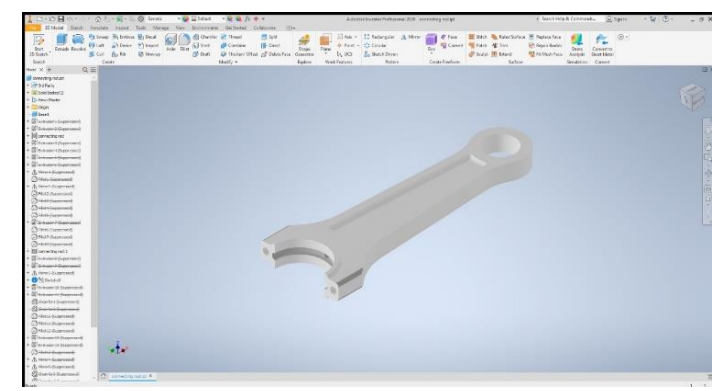

Gambar 3. Model 1

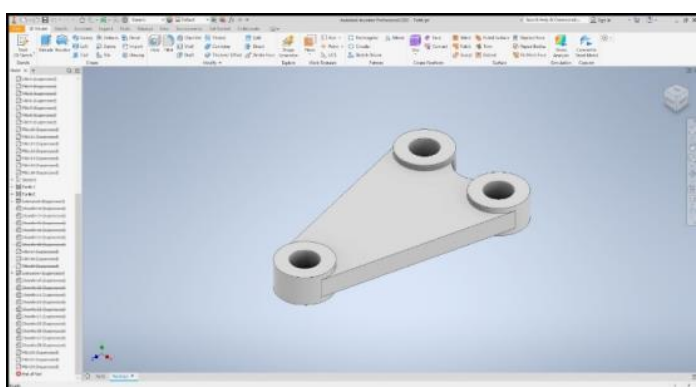

Gambar 4. Model 2

\section{Boundary condition}

Pada tahap ini model 1 dan model 2 di masing-masing salah satu sisi dikondisikan sebagai tumpuan jepit dan pada sisi lain yang dikondisikan sebagai sisi yang akan diberikan beban. Adapun besar gaya yang diberikan pada ke dua model adalah $1000 \mathrm{~N}$ dan $1500 \mathrm{~N}$. Berikut adalah gambar boundary condition dari model 1 dan 2.

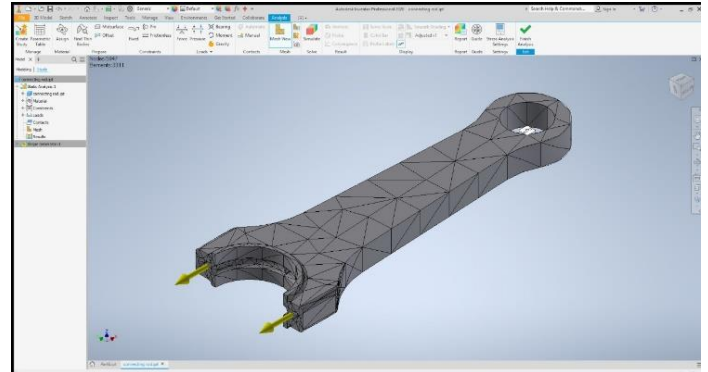

Gambar 5. Boundary condition model 1

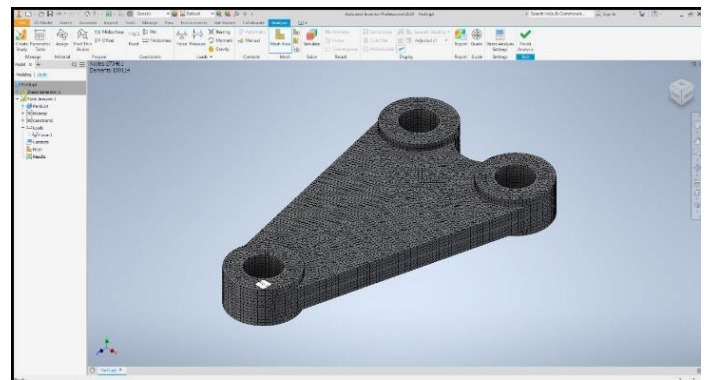

Gambar 6. Boundary condition model 2

3. Tahap Finite Element Analysis (FEA)

Pada tahap ini model diuji dengan dengan metode FEA untuk mengetahui besaran tegangan yang terjadi, berikut adalah gambar hasil pengujian dengan metode FEA.
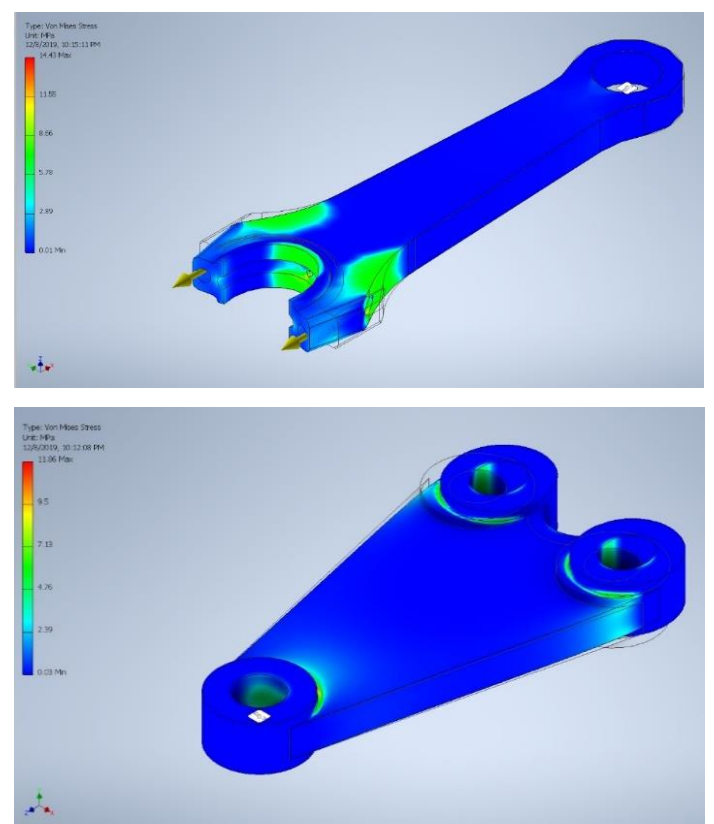

Gambar 7. Hasil simulasi FEA

\section{Tahap Optimasi Topologi}

Salah satu fitur dalam perangkat lunak Autodesk Inventor adalah shape generator dimana ini merupakan sebuah konsep generative design yang diterapkan untuk melakukan optimasi topologi dari bentuk/model yang telah ada sebelumnya. 
Penerapan optimasi ini mengendepankan kekakuan dalam melakukan optimasi terhadap bobot/massa dari model geometri berdasarkan sejumlah batasan dan kriteria desain yang dimasukkan [5]. Berikut adalah tahapan optimasi topologi :

1) Geometri awal yang merupakan 2 buah model dengan material PLA yang dikondisikan sama seperti pada Gambar 5 dan 6.

2) Tahap selanjutnya adalah mempertahan area geometri (preserve region), yaitu area yang tidak boleh terjadi perubahan dalam hal ini adalah pengurangan material. Pada tahap ini juga dilakukan constraint dan gaya.

3) Tahap selanjutnya model 1 dan 2 dilakukan pengurangan material oleh komputasi dengan metode generative dan akan menghasilkan bantuk baru namun masih dalam area dalam penampan mula-mula, dan setelah hasil dari generative ini ditransfer ke CAD kembali untuk dilakukan idealisasi bentuk dengan mempertimbangkan manufactureability.

4) Model yang telah dilakukan idealisasi diuji kembali dengan metode FEA untuk mengetahui besaran tegangan yang terjadi terjadi. Proses ini dilakukan dengan batasan volume da bagian tumpuan agar proses pengurangan material menghindari area ini. Selain itu batasan lain adalah parameter massa, pengurangan massa dilakukan dengan persentase $50 \%, 60 \%, 70 \%$ setiap kondisi pengurangan massa akan dihasilkan sesuai dengan kriteria tersebut.

\section{Penyetelan Printer 3 Dimensi dan Pencetakan Model}

Melakukan penyetelan pada printer 3 dimensi, simulasi proses pembuatan produk model dengan konsep generative design dapat memberikan kemudahan dimana proses pembuatan dapat dilihat tanpa membuat komponen secara langsung, dengan begitu maka kesalahan produksi dapat diminimalisir ataupun dihilangkan serta dapat menghemat waktu dan biaya.
Adapun parameter yang dilakukan untuk pencetakan model adalah sebagai berikut :

1) Menetukan layer height, dalam penelitia ini digunakan $0,15 \mathrm{~mm}$

2) Kecepatan pencetakan $60 \mathrm{~mm} / \mathrm{s}$

3) Penentuan infill, yaitu sebesar $70 \%$

4) Suhu pencetakan digunakan $2050 \mathrm{C}$

5) Penantuan support jika diperlukan

6) Pemrosesan G code

Berikut adalah gambar 3D Printer yang digunakan dalam penelitian ini, yaitu TRONXY.

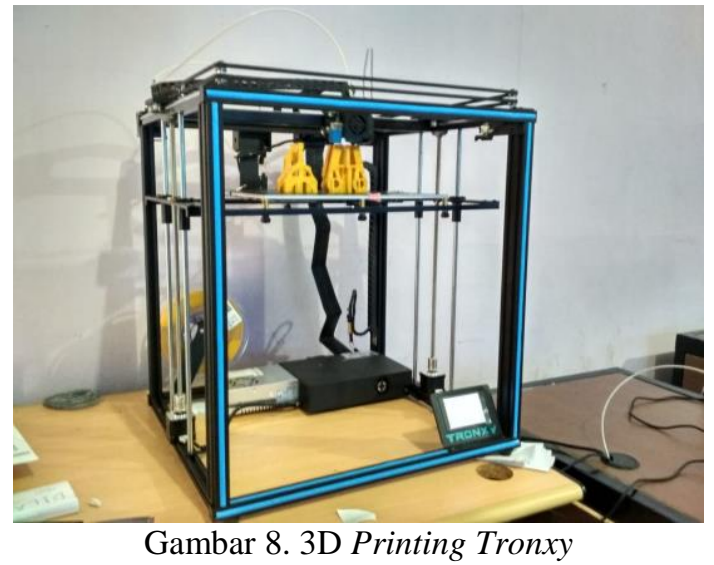

Khusus untuk penentuan suhu dilakukan pengujian dengan model bertingkat, seperti yang terlihat pada Gambar 9.

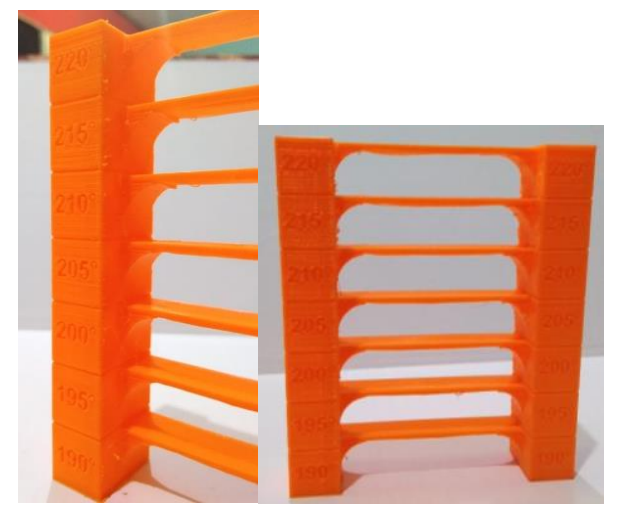

Gambar 9. Pengujian temperatur pencetakan

Adapun tahapan penelitian ini dapat dilihat pada diagram alir Gambar 10. 


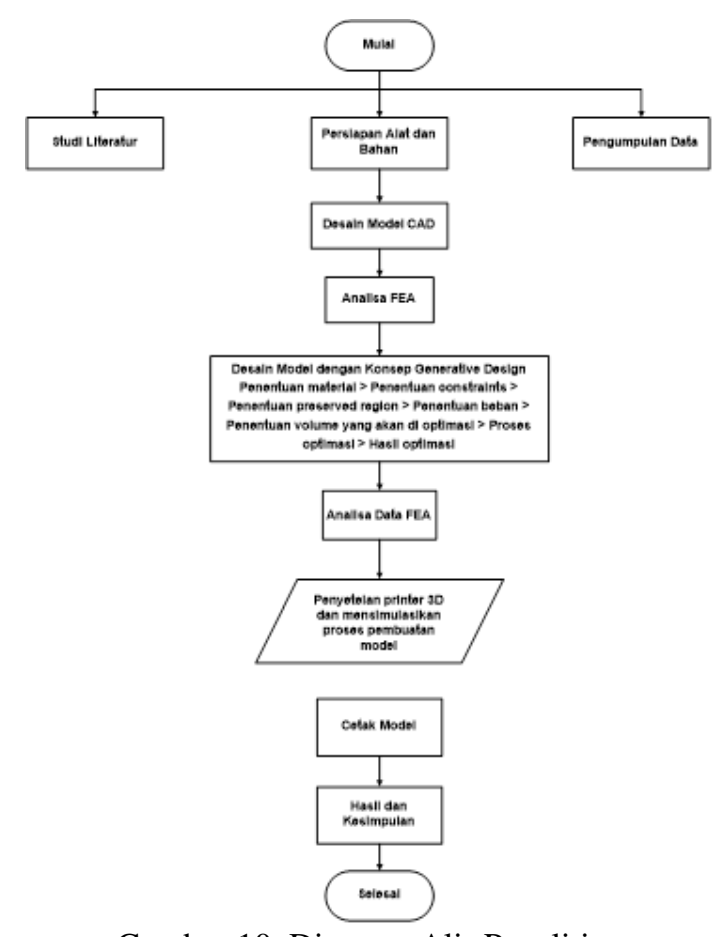

Gambar 10. Diagram Alir Penelitian

\section{Hasil dan Pembahasan}

\section{Model 1}

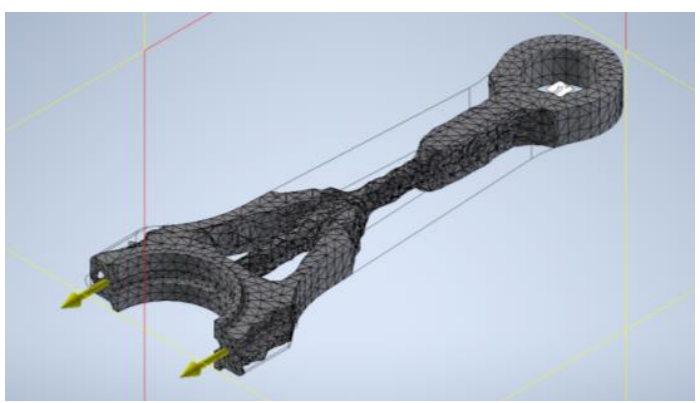

(a)

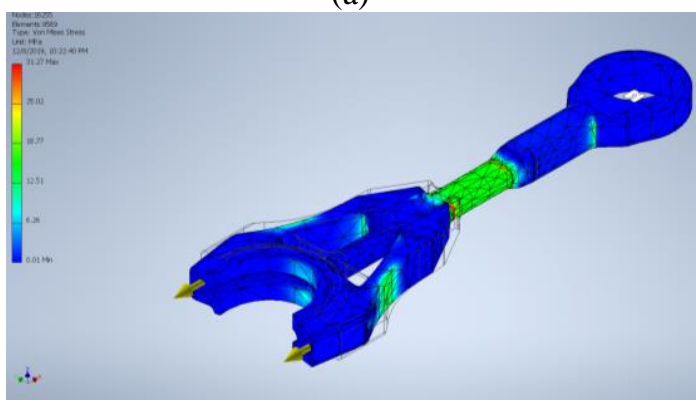

(b)

Gambar 11. Hasil optimalisasi topologi Model 1 pengurangan massa 50\%, (a) Massa akhir $0.23 \mathrm{~kg}$,

(b) Von Mises stress maksimum : $31.27 \mathrm{MPa}$.

Dari hasil optimalisasi pada model 1 dengan pengurangan material sebesar $50 \%$ terlihat bahwa Von Mises Stress maksimumnya sebesar 31,27 MPa. Walaupun kalau dilihat dari persentase degradasi warna nya kecil.

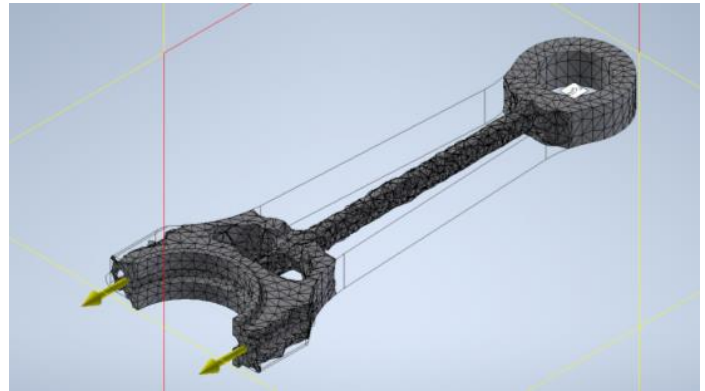

(a)

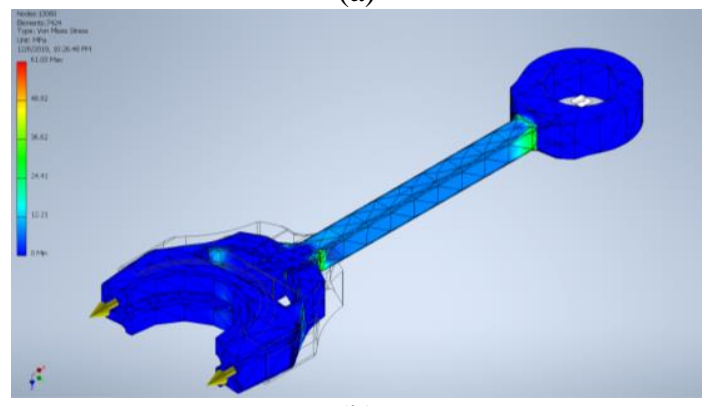

(b)

Gambar 12. Hasil optimalisasi topologi Model 1 pengurangan massa $60 \%$, (a) Massa akhir $0.189 \mathrm{~kg}$,

(b) Von Mises stress maksimum : $61.03 \mathrm{MPa}$.

Untuk model 1 dengan pengurangan material sebesar $60 \%$ terlihat bahwa Von Mises Stress maksimumnya meningkat menjadi 57,22 $\mathrm{MPa}$.

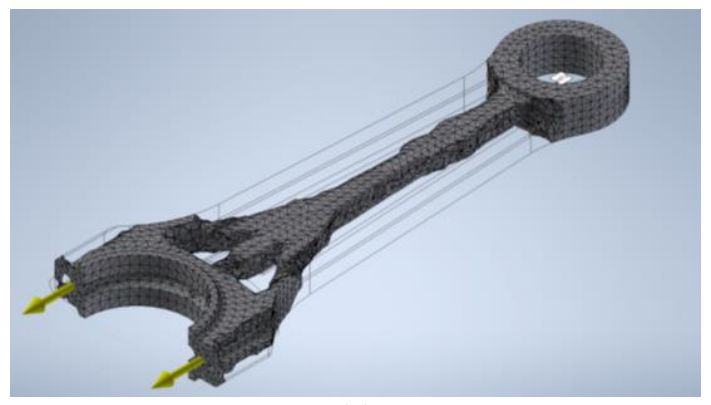

(a)

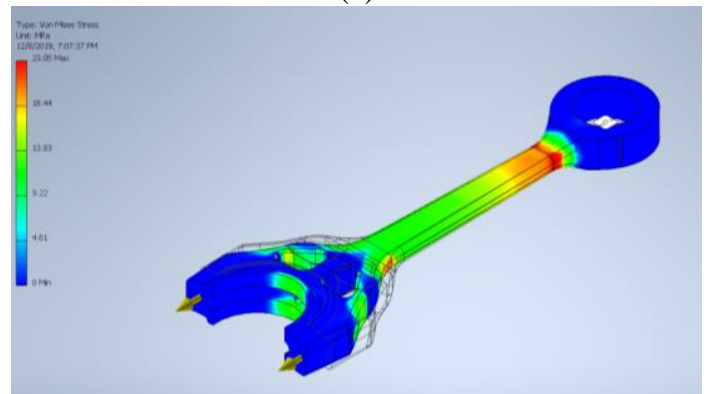

(b)

Gambar 13. Hasil optimalisasi Model 1 pengurangan massa 70\%, (a) Massa akhir $0.107 \mathrm{~kg}$, (b) Von Mises stress maksimum : $23.05 \mathrm{MPa}$.

Sedangkan untuk model 1 dengan pengurangan material sebesar $70 \%$ terlihat bahwa Von Mises Stress maksimumnya turun menjadi 23,05 $\mathrm{MPa}$. 
Ketiga hal tersebut diduga bahwa dilihat dari bentuk hasil optimasi topologi dengan generative design pada model 1 dengan pengurangan material $50 \%$ dan 60 $\%$ banyak terdapat daerah-daerah yang tajam walaupun pada daerah tersebut sudah dilakukan modifikasi dengan bentuk fillet atau radius. Dugaan lain adalah akurasi dari software yang membaca adanya satu daerah yang sangat kecil dengan konsentrasi tegangan tinggi, yang seharusnya dapat diabaikan, namun pada saat perhitungan secara komputasi terdeteksi.

\section{Model 2}

Dari hasil optimalisasi pada model 2 dengan pengurangan material sebesar $50 \%$ terlihat bahwa Von Mises Stress maksimumnya sebesar 15,55 MPa. Untuk model 2 dengan pengurangan material sebesar $60 \%$ terlihat bahwa Von Mises Stress maksimumnya meningkat menjadi $360 \mathrm{MPa}$.

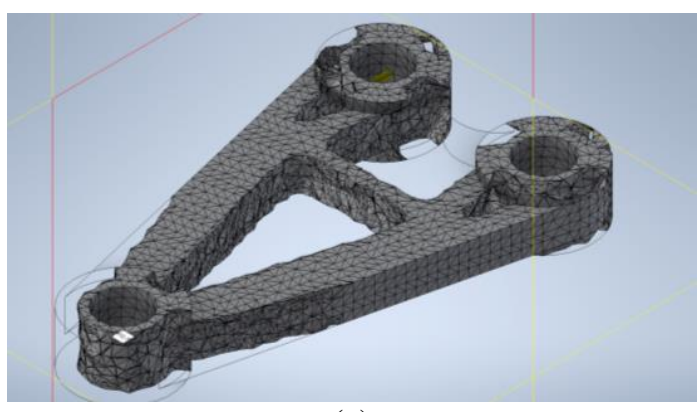

(a)

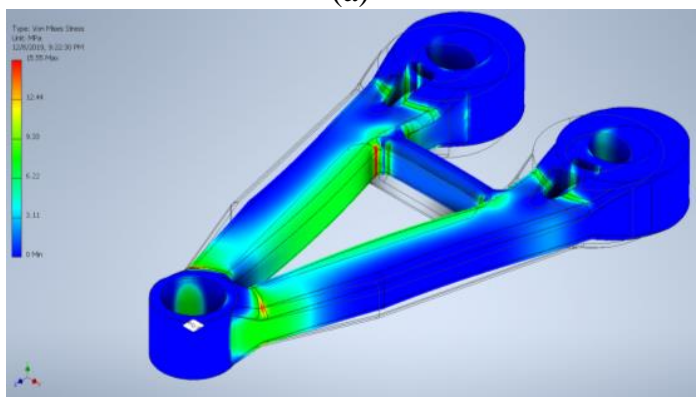

(b)

Gambar 14. Hasil optimalisasi Model 2 pengurangan massa 50\%, (a) Massa akhir 0.0482 $\mathrm{kg}$, (b) Von Mises stress maksimum : 15.55 MPa.

Sedangkan untuk model 2 dengan pengurangan material sebesar $70 \%$ terlihat bahwa Von Mises Stress maksimumnya turun menjadi $32,48 \mathrm{MPa}$.

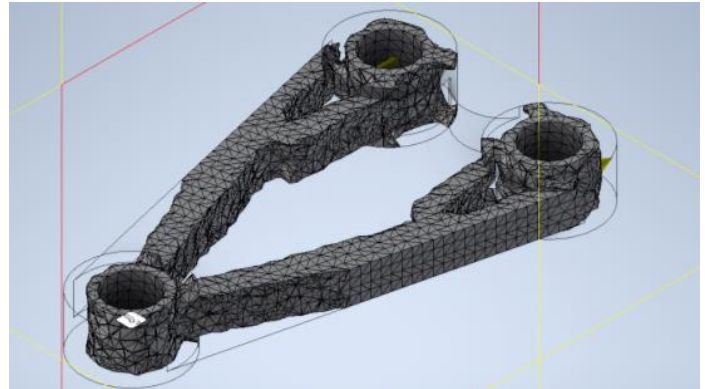

(a)

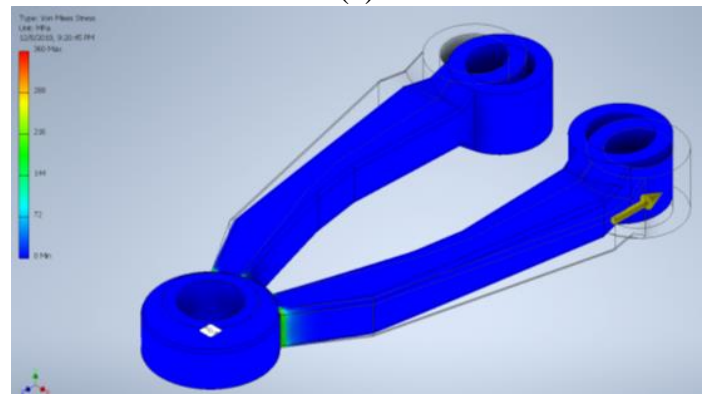

(b)

Gambar 15. Hasil optimalisasi Model 2 pengurangan massa $60 \%$, (a) Massa akhir 0.0321 $\mathrm{kg}$, (b) Von Mises stress maksimum : $360 \mathrm{MPa}$.

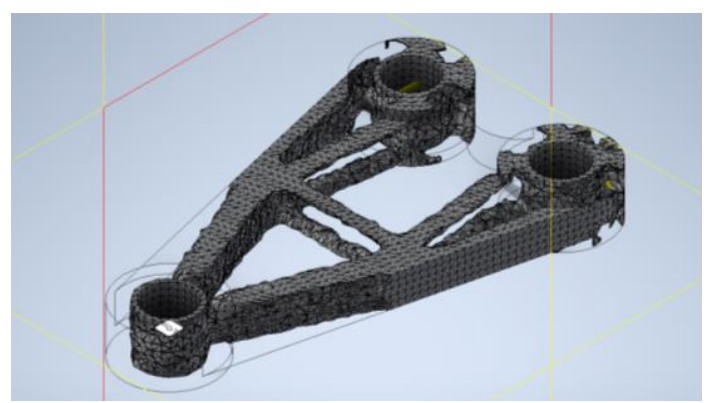

(a)

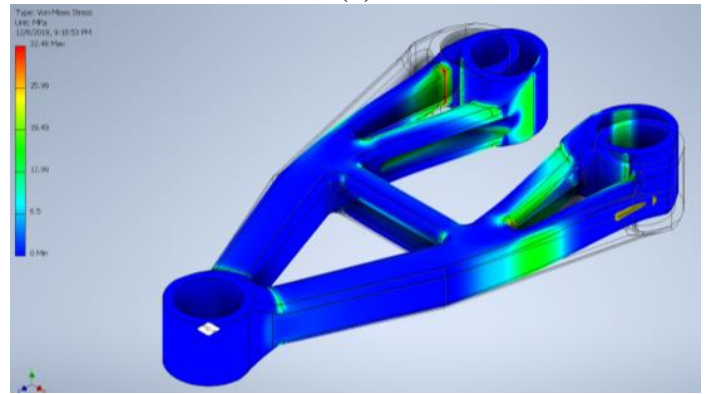

(b)

Gambar 16. Hasil optimalisasi Model 2 pengurangan massa 70\%, (a) Massa akhir 0.0274 $\mathrm{kg}$, (b) Von Mises stress maksimum : $32.48 \mathrm{MPa}$.

Untuk model 2 dengan pengurangan material $60 \%$ terjadi nilai Von Mises Stress maksimumnya sangat tinggi, hal ini diduga karena pada bagian tengan mdel 2 kosong. Terdapat bagian konsentrasi tegangan di daerah yang sempit sekali, sehingga sulit untuk menguarangi konsentrasi tegangan tersebut dengan memberikan fillet. 
Sementara itu untuk model 2 dengan pengurangan material $50 \%$ dan $70 \%$ secara bentuk hampir sama. Tetapi untuk $50 \%$ daerah merahnya lebih banyak dibandingkan dengan yang $70 \%$.

\section{Hasil pencetakan}

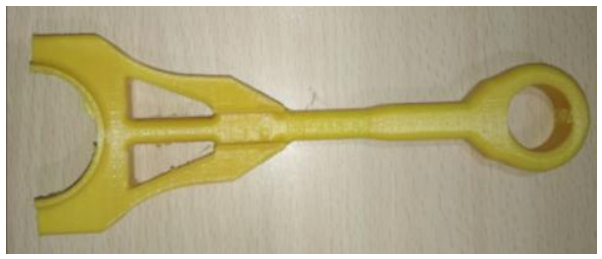

(a)

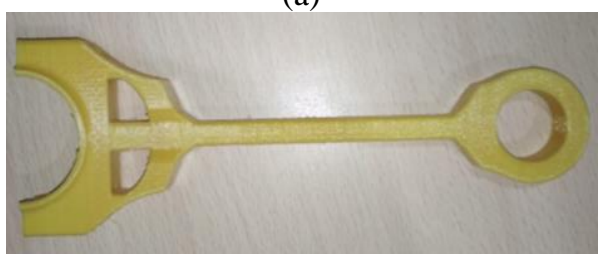

(b)

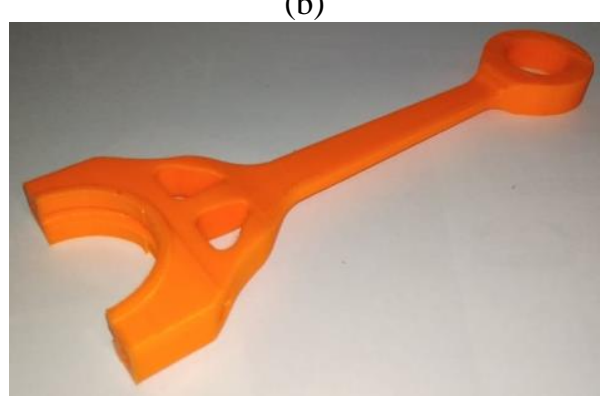

(c)

Gambar 17. Hasil 3D printing model 1dengan pengurangan material (a) 50\%, (b) $60 \%$, (c) $70 \%$

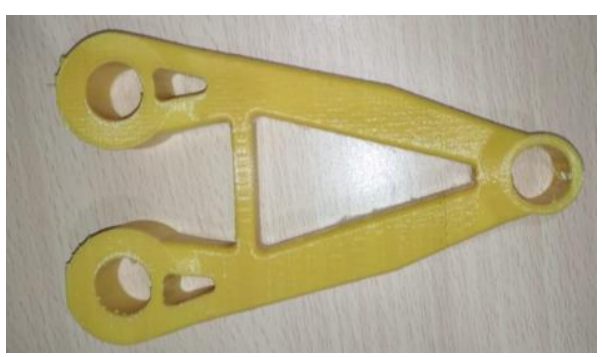

(a)

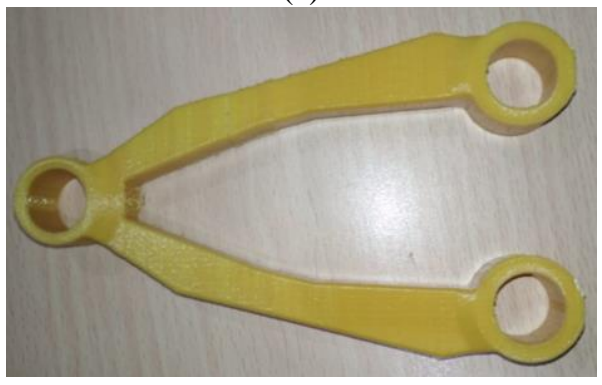

(b)

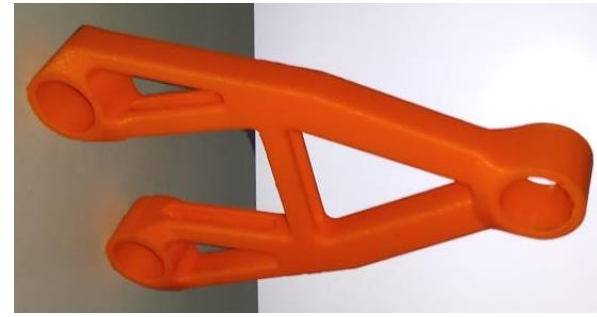

(c)

Gambar 18. Hasil 3D printing model 2 dengan pengurangan material (a) 50\%, (b) $60 \%$, (c) $70 \%$

Untuk hasil pencetakan terdapat banyak stringhing (berbulu) pada saat pencetakan lebih dari satu model. Selain itu, terjadi cacat akibat pergerakan filament pada extruder terlambat, sehingga hasil dinding layer tidak sempurna.

\section{Kesimpulan}

Model 1 dengan pengurangan material sebesar $70 \%$ bentuk optimasi topologi lebih baik dibandingkan dengan penguarangan material $50 \%$ maupun $60 \%$. Dengan infill $70 \%$ seharusnya Tensile Strength nya sebesar 20,16 MPa, tetapi dari hasil perhitungan komputasi Von Mises Stress maksimumnya lebih tinggi dari Tensile Strength, karena hal ini dipengaruhi oleh bentuk model yang lebih komplit. Untuk model 2 pengurangan material $50 \%$ Von Mises Stress maksimumnya lebih kecil dibandingkan dengan pengurangan $60 \%$ dan $70 \%$. Namun daerah yang berwarna merah untuk pengurangan material $50 \%$ lebih banyak.

Masih diperlukan beberapa variasi alternative model dengan optimasi topologi menggunakan konsep generative design. Selain itu, hasil pencetakan masih perlu dilakukan pengujian mekanik untuk mengetahui kekuatan yang sebenarnya setelah dilakukan optimasi topologi.

\section{Ucapan Terimakasih}

Ucapan terima kasih peneliti sampaikan kepada Jurusan Teknik Mesin Polnep atas bantuan dana yang dianggarkan melalui dana PNBP, hingga selesainya penelitian ini. 


\section{Referensi}

[1]. Sujanayogi. 2010. Mesin CNC. Bandung: Fakultas Teknologi Industri ITB.

[2]. Special Report: Generative Design and Topology Optimization by Altair, diunduh 16 April 2019, dari https://www.altair.com/

[3]. Pambudi, A.I. 2017. Analisis Pengaruh Internal Geometri Terhadap Sifat Mekanik Meterial Polylactic Acid (PLA) dipreparasi Menggunakan 3D Printing. Surabaya: Fakultas Teknologi Industri ITS.

[4]. Izabela Hager, Anna Golonka, Roman Putanowicz, " 3 D printing of buildings and building components as the future of sustainable construction." Procedia Engineering 151, 292 - 299, 2016.

[5]. D.W. Utama, "Optimasi topologi pada komponen penampan mesin printer 3 dimensi dengan metode generative desain", Jurnal Dinamika Teknik Mesin, Vol. 7, 2017. 